\title{
Moisture conservation practices and nutrient management on growth and yield of rabi sorghum (Sorghum bicolor) in the vertisols of peninsular India
}

\author{
Mudalagiriyappa*, B. K. Ramachandrappa, H. V. Nanjappa \\ Department of Agronomy, University of Agricultural Sciences, Bangalore, India; *Corresponding Author: mudal68@yahoo.com
}

Received 26 March 2012; revised 27 April 2012; accepted 8 May 2012

\begin{abstract}
The effect of moisture conservation and nutrient management on growth and yield of rabi sorghum was studied at the Zonal Agricultural Research Station, Babbur Farm, Hiriyur Karnataka under rainfed conditions on medium black soil during rabi seasons of 2007-2008 and 2008-2009. Paired row planting $(30-60-30 \mathrm{~cm})$ and opening of furrow in wide rows at 35 Days After Sowing (DAS) proved superior over sowing across the slope and even ridges and furrows with tied ridging in terms of grain yield (1.10 t/ha), stover yield (1.51 t/ha) and 1000 grain weight $(24.6 \mathrm{~g})$. Similarly application of $50 \%$ recommended dose of fertilizer (RDF + Farm Yard Manure (FYM) 2.5 t/ha + Microbial consortia (Trichoderma, Azospirillum and Phosphate Solubilizing Bacteria (PSB) recorded significantly higher plant height (121 $\mathrm{cm})$, panicle length $(8.7 \mathrm{~cm})$, panicle diameter $(7.4 \mathrm{~cm}), 1000$ grain weight $(24.3 \mathrm{~g})$, grain yield ( $0.95 \mathrm{t} / \mathrm{ha}$ ) and stover yield (1.42 t/ha) over other treatments but on par with the application of $100 \%$ RDF + FYM 2.5 t/ha. Paired row planting (30-60-30 cm) and opening of furrow in wide rows at 35 DAS was also superior with maximum output energy of $43350 \mathrm{MJ} / \mathrm{ha}$, rainwater use efficiency of $5.15 \mathrm{Kg} / \mathrm{ha} / \mathrm{mm}$ and $B C$ ratio of 2.31 . Similarly application of 50\% RDF + FYM 2.5 t/ha + Microbial consortia recorded higher output energy of $39525 \mathrm{MJ} / \mathrm{ha}$ and rainwater use efficiency of $4.48 \mathrm{Kg} / \mathrm{ha} / \mathrm{mm}$.
\end{abstract}

Keywords: Nutrient Management; Paired Row Planting; Moisture Conservation; Energy Use Efficiency; Tied Ridging; rabi Sorghum; Yield

\section{INTRODUCTION}

Rabi sorghum (Sorghum bicolor L.) is the most impor- tant post rainy season (rabi) cereal crop in peninsular India, grown predominantly under rain fed conditions. The area under rabi sorghum is mainly concentrated in semi arid region of Deccan plateau consisting the states like Maharashtra, Karnataka and Andhra Pradesh. There is an evidence of stagnation or decline in the productivity of rabi sorghum even with the application of recommended dose of fertilizer under rainfed areas. Limited and erratic rainfall in the rainfed areas makes rabi sorghum vulnerable to moisture stress conditions during the later part of its growth, resulting in severe yield reduction. Moisture conservation therefore plays a key role in the successful crop production of rabi sorghum in the vertisols of peninsular India.

Adequate soil moisture is the key to successful crop production in dry land areas (Ajay Kumar and Rana [1]) It is therefore crucial that farming systems in these regions aim at making the maximum use of incident rainfall by ensuring that wasteful surface runoff is avoided. Hence, the conservation, development and management of the land resources are of prime importance (Khanapara et al. [2]). Positive yield responses to various moisture conservation techniques are therefore commonly observed on medium black soils of the semi arid tropics. Use of organic manures and planting methods are effective in increasing the productivity and water use by rabi sorghum under rainfed conditions. Another way of reducing runoff is prolonging the infiltration opportunity time in the soil in wide furrows. This effect can be caused by the use of tide ridging, that is ridges which are tied by earthen bunds and paired row planting and opening of a deep furrow after sowing of the crop. The importance of energy in cropping systems has been discussed in detail by Singh et al. [3] and Jat et al. [4]. Effect of tillage practices on yield (Nema et al. [5]) energy use pattern in cluster bean-pearl millet by Patidar and Singh [6] were well documented. Improving the rain water use efficiency would be essential for optimizing the benefit of in-situ water harvesting.

Relatively little is known about the response of rabi 
sorghum to moisture conservation and nutrient management including microbial consortia under drought conditions of central dry zone of Karnataka, India. Hence this study on the effect of moisture conservation practice and nutrient management on growth and grain yield of rabi sorghum has been undertaken.

\section{MATERIALS AND METHODS}

\subsection{Experimental Details}

The experiment was conducted on a medium black soil at the Zonal Agricultural Research Station, Babbur Farm, Hiriyur in two consecutive post rainy (rabi) seasons (2007-2008 and 2008-2009). This location has a typical semi arid and subtropical climate characterized by hot dry summer and cool winter. The soil at the experimental site was characterized with a $\mathrm{pH}$ (8.2), EC $\left(0.28 \mathrm{dS} \cdot \mathrm{m}^{-1}\right)$ and available $\mathrm{N}(257.2 \mathrm{~kg} / \mathrm{ha}), \mathrm{P}(13.48$ $\mathrm{kg} / \mathrm{ha}$ ) and $\mathrm{K}$ (325 kg/ha). The experimental field was medium black soil and the experiment was laid out in a split-plot design with three replications. The treatment combinations comprised of three moisture conservation practices viz., sowing across the slope, ridges and furrows with tied ridging and paired row planting and opening of furrows in wide rows at 35 DAS. The four nutrient treatments viz., 100\% RDF (50 - $10.91 \mathrm{~N}-\mathrm{P} \mathrm{kg} / \mathrm{ha})+$ FYM 2.5 t/ha, 50\% RDF + FYM 2.5 t/ha, 50\% RDF + Microbial consortia and 50\% RDF + FYM 2.5 t/ha + Microbial consortia were also tried with 12 treatment combinations.

Before the start of rabi crop field was ploughed and laid out as per the design. After the first rain, fertilizers were applied as per the treatments. All fertilizers and FYM were applied 2 weeks before planting. The farm yard manure used for the study had $0.65 \% \mathrm{~N}, 0.40 \%$ $\mathrm{P}_{2} \mathrm{O}_{5}$ and $0.60 \% \mathrm{~K}_{2} \mathrm{O}$ ). In the plots of sowing across the slope and paired row planting, the fertilizer was placed 5 $\mathrm{cm}$ below soil surface and $5 \mathrm{~cm}$ to the side of the planting row. In tied ridging plots the fertilizer was applied before making the ridges. A known quantity (500 gm/ha) of Azospirillum brasilense, Trichoderma viride and Pseudomonas striata (Phospate Solubilizing Bacteria) were mixed and seeds were treated uniformly and sown wherever microbial consortia was included. M-35-1 variety of rabi sorghum was used for sowing during both the years. The crop was sown on September $27^{\text {th }}$ and September $15^{\text {th }}$ during 2007-2008 and 2008-2009 respectively. The rabi sorghum seeds were sown at field capacity with a seed rate of $7.5 \mathrm{~kg} / \mathrm{ha}$. The spacing between row to row was maintained at $45 \mathrm{~cm}$ where as paired row spacing was done at a distance of $30 \mathrm{~cm}$, keeping the distance between the two pairs of rows was $60 \mathrm{~cm}$ and the observations were recorded after the harvest of the crop. Runoff and soil loss were completely prevented since every treatment was bounded on all four sides. Observations were recorded on sorghum grain yield ( $\mathrm{t} / \mathrm{ha}$ ), stover yield (t/ha), input energy (MJ/ha) of different operations, out put energy (MJ/ha), rain water use efficiency $(\mathrm{kg} / \mathrm{ha} / \mathrm{mm})$, monetary returns (Rs/ha) and benefit cost ratio under each treatment. The rain water use efficiency was calculated as a ratio of the grain yield attained by a treatment and the amount of rainfall received and runoff occurred from sowing to harvest.

\subsection{Rainfall and Its Distribution}

The rainfall received during the growing period from $27^{\text {th }}$ September 2007 to $30^{\text {th }}$ January 2008 was $278.2 \mathrm{~mm}$ with 10 rainy days. Similarly $15^{\text {th }}$ September 2008 to $21^{\text {st }}$ January 2009 was 149 mm with 9 rainy days. The rainfall received at different crop growth stages is given in Table 1. The annual rainfall received during 2007-2008 was much higher (934 mm) than 2008-2009 (639.4 mm), though the rainfall received during the cropping season of 2007-2008 was much higher (86\%) but the yield of rabi sorghum during first year was less mainly due to incidence of shoot fly because of delayed sowing. There was sufficient soil moisture at seeding, initial growth and panicle initiation stage.

\section{RESULTS AND DISCUSSION}

\subsection{Effect of Moisture Conservation and Nutrient Management Practices on the Productivity of Rabi Sorghum.}

The grain and stover yields of rabi sorghum were significantly influenced by moisture conservation practices during both the years. The highest grain yield (1.05 and $1.15 \mathrm{t} / \mathrm{ha}$ ) was recorded in paired row planting and opening of a furrow in wide rows at 35 DAS which was 118 and 40 per cent higher than with sowing across the slope during 2007-2008 and 2008-2009 respectively. This could be ascribed due to the reduced surface runoff and reduced risk of erosion and soil nutrients and also due to

Table 1. Rainfall (mm) received at different crop growth stages of rabi sorghum.

\begin{tabular}{cccc}
\hline Growth stages & 2007-2008 & 2008-2009 & Mean \\
\hline $\begin{array}{c}\text { Germination (0 - 7 days) } \\
\text { Knee height stage } \\
\quad(35 \text { - 45 days) }\end{array}$ & 184.42 & 22 & 42.71 \\
$\begin{array}{c}\text { Panicle initiation stage, } \\
\text { Milking and seed formation } \\
\text { stage (46 - 90 days) }\end{array}$ & 23 & 111.2 & 147.7 \\
Maturity (91 - 125 days) & 7.58 & 16 & 19.5 \\
$\begin{array}{c}\text { Crop seasonal rainfall (mm) } \\
\text { Annual rainfall (mm) }\end{array}$ & 278.2 & 149 & 3.79 \\
$\begin{array}{c}\text { No. of rainy days during } \\
\text { cropping period }\end{array}$ & 934 & 639.4 & 786.7 \\
\hline
\end{tabular}


increased water holding capacity of the soil. The results are in conformity with findings of Pacharne et al. [7]. Pooled data indicated that tied ridging and paired row planting recorded significantly higher panicle diameter (6.7 and $10 \mathrm{~cm}$ ) and 1000 grain weight (21.8 and $24.6 \mathrm{~g}$ ) during 2007-2008 and 2008-2009 respectively over sowing across the slope. The higher yield and yield components in moisture conservation treatments could be attributed to vigorous crop growth resulting from increased availability of soil moisture. Das and Goutham [8] reported similar results in pearl millet. The harvest index ranged from 39.90 under 50\% RDF + FYM $2.5 \mathrm{t} / \mathrm{ha}$, 50\% RDF + Microbial consortia to 42.36 under $100 \%$ RDF + FYM 2.5 t/ha. Paired row planting and opening of furrow in wide rows at 35 DAS recorded numerically higher harvest index of 42.12 among different moisture conservation treatments.

Plant height, panicle length, panicle diameter, yield per plant, 1000 grain weight, yield and stover yield showed significant variation due to nutrient management practices. Application of RDF + FYM recorded significantly higher average yield $(0.96 \mathrm{t} / \mathrm{ha})$ compared to other treatments except with 50\% RDF + FYM + Microbial consortia (0.95 t/ha). Similarly stover yield, panicle length, panicle diameter and 1000 grain weight were significantly higher in RDF + FYM + Microbial consortia and $50 \%$ RDF + FYM + Microbial consortia. This was mainly due to increased water holding capacity of the soil with increased nutrient content in grain and stover by providing balanced nutritional environment inside the plant and higher photosynthetic efficiency and ncreased microbial activity which in turn might have resulted in profuse shoot and root growth in the above treatments and there by activating greater absorption of nutrients from the soil, leading to improved grain and stover yields. Ajay Kumar and Rana [1] reported that application of nutrient along with FYM and PSB recorded higher pigeon pea equivalent yield, water use and net returns. Similarly Patil et al. [9] reported that moisture conservation practice along with 50\% RDF and biofertilizer was beneficial. The interaction effect between soil moisture conservation and nutrient management found to be significant only on yield of rabi sorghum.

\subsection{Effect of Moisture Conservation and Nutrient Management Practices on Nutrient Uptake}

Uptake of $\mathrm{N}$ and $\mathrm{P}$ varied significantly due to different treatments. Paired row planting recorded significantly higher N (46.8 kg/ha) and P (8.6 kg/ha) uptake over other treatments (Table 3). Similarly, RDF + FYM recorded significantly higher $\mathrm{N}$ and $\mathrm{P}$ uptake but on par with $50 \%$ RDF + FYM + Microbial consortia. Similar results were reported by Rathore et al. [10]. The increased uptake of $\mathrm{N}$ and $\mathrm{P}$ under these treatments could be attributed to higher grain and stover yields, apparently because of increased availability of water to the plants. Adequate supply of moisture in general is known to influence positively on the growth and dry matter production of crop directly as well as indirectly by increasing the availability and utilization of nutrient.

Table 2. Effect of soil moisture conservation and nutrient management practices on growth and yield of rabi sorghum.

\begin{tabular}{|c|c|c|c|c|c|c|c|c|c|c|c|c|c|c|}
\hline \multirow{2}{*}{$\begin{array}{l}\text { Moisture Conservation } \\
\text { Practice }\end{array}$} & \multicolumn{2}{|c|}{$\begin{array}{l}\text { Plant height } \\
(\mathrm{cm})\end{array}$} & \multicolumn{2}{|c|}{$\begin{array}{l}\text { Panicle length } \\
\text { (cm) }\end{array}$} & \multicolumn{2}{|c|}{$\begin{array}{c}\text { Panicle } \\
\text { diameter }(\mathrm{cm})\end{array}$} & \multicolumn{2}{|c|}{$\begin{array}{l}1000 \text { grain } \\
\text { weight }(\mathrm{g})\end{array}$} & \multicolumn{2}{|c|}{$\begin{array}{l}\text { Grain yield } \\
\text { (t/ha) }\end{array}$} & \multicolumn{2}{|c|}{$\begin{array}{l}\text { Stover yield } \\
\text { (t/ha) }\end{array}$} & \multicolumn{2}{|c|}{ Harvest index \% } \\
\hline & $\begin{array}{l}2007- \\
2008\end{array}$ & $\begin{array}{l}2008- \\
2009\end{array}$ & $\begin{array}{l}2007- \\
2008\end{array}$ & $\begin{array}{l}2008- \\
2009\end{array}$ & $\begin{array}{l}2007- \\
2008 \\
\end{array}$ & $\begin{array}{l}2008- \\
2009\end{array}$ & $\begin{array}{c}2007- \\
2008\end{array}$ & $\begin{array}{l}2008- \\
2009\end{array}$ & $\begin{array}{l}2007- \\
2008\end{array}$ & $\begin{array}{c}2008- \\
2009\end{array}$ & $\begin{array}{l}2007- \\
2008\end{array}$ & $\begin{array}{l}2008- \\
2009 \\
\end{array}$ & $\begin{array}{l}2007- \\
2008\end{array}$ & $\begin{array}{c}2008- \\
2009\end{array}$ \\
\hline Sowing across the slope & 98 & 105 & 4.7 & 6.6 & 6.6 & 5.4 & 22.3 & 21.4 & 0.48 & 0.82 & 0.90 & 0.98 & 34.78 & 45.55 \\
\hline $\begin{array}{l}\text { Ridges and furrows with } \\
\text { tied ridging }\end{array}$ & 103 & 112 & 6.3 & 8.2 & 5.1 & 8.2 & 21.1 & 22.5 & 0.64 & 0.99 & 1.15 & 1.23 & 35.75 & 44.59 \\
\hline $\begin{array}{l}\text { Paired row planting and } \\
\text { opening of furrows in } \\
\text { wide rows at } 35 \text { DAS }\end{array}$ & 124 & 122 & 9.9 & 10.2 & 9.3 & 10.7 & 24.4 & 24.7 & 1.05 & 1.15 & 1.47 & 1.55 & 41.66 & 42.59 \\
\hline $\mathrm{SEm} \pm$ & 2 & 4.05 & 0.22 & 0.99 & 0.27 & 0.22 & 0.16 & 0.16 & 0.04 & 0.02 & 0.13 & 0.04 & - & - \\
\hline $\mathrm{CD}(\mathrm{P}=0.05)$ & 6 & 12.4 & 0.65 & 2.96 & 0.80 & 0.65 & 0.48 & 0.47 & 0.13 & 0.07 & 0.42 & 0.11 & - & - \\
\hline \multicolumn{15}{|l|}{ Nutrient management } \\
\hline $100 \%$ RDF + FYM 2.5 t/ha & 127 & 122 & 7.98 & 9.4 & 6.6 & 8.7 & 24.9 & 25.2 & 0.83 & 1.08 & 1.25 & 1.33 & 39.90 & 44.81 \\
\hline $\begin{array}{l}50 \% \text { RDF + } \\
\text { Microbial consortia }\end{array}$ & 102 & 105 & 5.8 & 7.2 & 4.8 & 6.5 & 20.9 & 21.1 & 0.60 & 0.86 & 1.02 & 1.10 & 37.03 & 43.87 \\
\hline $\begin{array}{l}50 \% \text { RDF + FYM } 2.5 \text { t/ha } \\
+ \text { Microbial consortia }\end{array}$ & 125 & 116 & 8.0 & 9.4 & 6.1 & 8.7 & 24.1 & 24.4 & 0.82 & 1.08 & 1.38 & 1.46 & 37.27 & 42.52 \\
\hline $\mathrm{Em} \pm$ & 4.92 & 7.4 & 0.22 & 0.26 & 0.27 & 0.22 & 0.34 & 0.35 & 0.02 & 0.03 & 0.05 & 0.04 & - & - \\
\hline $\mathrm{CD}(\mathrm{P}=0.05)$ & 14.1 & 22.4 & 0.76 & 0.80 & 1.24 & 0.89 & 1.14 & 1.21 & 0.06 & 0.09 & 0.14 & 0.13 & - & - \\
\hline
\end{tabular}

RDF: Recommended Dose of Fertilizer; FYM: Farm Yard Manure; DAS: Days after Sowing. 
Table 3. Effect of soil moisture conservation and nutrient management practices on nutrient uptake and economics of rabi sorghum (Pooled).

\begin{tabular}{|c|c|c|c|c|c|}
\hline \multirow{2}{*}{$\begin{array}{l}\text { Moisture Conservation } \\
\text { Practice }\end{array}$} & \multirow{2}{*}{$\begin{array}{l}\text { Total N uptake } \\
\text { kg/ha }\end{array}$} & \multirow{2}{*}{$\begin{array}{l}\text { Total P uptake } \\
\mathrm{kg} / \mathrm{ha}\end{array}$} & \multirow{2}{*}{$\begin{array}{l}\text { RWUE } \\
\mathrm{Kg} / \mathrm{ha} / \mathrm{mm}\end{array}$} & \multicolumn{2}{|c|}{ Economics } \\
\hline & & & & Net returns Rs./ha & $\mathrm{B}: \mathrm{C}$ ratio \\
\hline Sowing across the slope & 31.9 & 6.90 & 3.04 & 3012 & 1.45 \\
\hline $\begin{array}{l}\text { Ridges and furrows with tied } \\
\text { ridging }\end{array}$ & 38.4 & 7.4 & 3.82 & 4863 & 1.65 \\
\hline $\begin{array}{c}\text { Paired row planting and opening } \\
\text { of furrows in wide rows at } 35 \\
\text { DAS }\end{array}$ & 46.8 & 8.6 & 5.15 & 9362 & 2.31 \\
\hline $\mathrm{SEm} \pm$ & 2.44 & 0.11 & & - & - \\
\hline $\mathrm{CD}(\mathrm{P}=0.05)$ & 7.1 & 0.32 & & - & - \\
\hline \multicolumn{6}{|l|}{ Nutrient Management } \\
\hline $100 \%$ RDF + FYM 2.5 t/ha & 56.2 & 9.2 & 4.47 & 7662 & 2.14 \\
\hline $50 \%$ RDF + FYM 2.5 t/ha & 38.6 & 8.1 & 3.53 & 4262 & 1.60 \\
\hline $50 \%$ RDF + Microbial consortia & 33.6 & 7.4 & 3.42 & 5712 & 2.09 \\
\hline $\begin{array}{l}50 \% \text { RDF +FYM } 2.5 \text { t/ha + } \\
\text { Microbial consortia }\end{array}$ & 50.8 & 8.8 & 4.48 & 7262 & 2.03 \\
\hline $\mathrm{SEm} \pm$ & 3.17 & 0.21 & & - & - \\
\hline $\mathrm{CD}(\mathrm{P}=0.05)$ & 9.2 & 0.60 & & - & - \\
\hline
\end{tabular}

RDF: Recommended Dose of Fertilizer; FYM: Farm Yard Manure; DAS: Days after Sowing.

\subsection{Effect of Moisture Conversation and Nutrient Management Practices on the Profitability of Rabi Sorghum}

The cost of inputs viz., Seeds, fertilizers and chemicals was Rs.2937/ha-which was almost same for all the moisture conservation practices but slightly varies in nutrient man agent treatments depending upon the fertilizers and manures applied. The overall cost of cultivation was maximum (Rs.7434/ha) in case of paired row planting and opening of furrow in wide rows at 35DAS and tied ridging.

Moisture conservation practices brought about considerable variation in net return and B:C ratio. Maximum net return (Rs.9362/ha) and B:C ratio (2.31) was recorded with paired row planting. This was mainly due to higher yields obtained in the treatment. 50\% RDF + FYM + Microbial consortia recorded almost similar net return and B:C ratio compared to 100\% RDF + FYM 2.5 t/ha.

\subsection{Effect of Moisture Conservation \& Nutrient Management Practices on Energy Productivity and Efficiency}

The input energy of application of treatment and sowing, the total input energy (MJ/ha), the total output energy, energy use efficiency and energy productivity (g/MJ) of different moisture conservation practices in rabi sorghum over two years are given in Table 4. The input energy was almost same for all the three moisture conservation practices and it was varied in different nutrient management practices. The input energy was highest for fertilizer and manures (4057 MJ/ha) followed by harvesting and processing (314 MJ/ha), weeding (157.8 MJ/ha) seed (102.5 MJ/ha), and land preparation for sowing through bullocks (161.6 MJ/ha). The maximum total input energy of $4919 \mathrm{MJ} / \mathrm{ha}$ was observed under ridges and furrow with tied ridging followed by paired row planting and opening of furrows in wide rows at 35 DAS (4872 MJ/ha). The sowing across the slope had the lowest input energy of $4792 \mathrm{MJ} / \mathrm{ha}$.

Among different operations fertilizers and manure contributed about $84 \%$ and harvesting and processing contributed about $6.5 \%$ to total input energy in rabi sorghum. The harvested grain and fodder yields obtained under different treatments were converted to output energy (MJ/ha). The results indicated that maximum output energy of 43,350 MJ/ha was attained under paired row planting and opening of furrow in wide rows at 35DAS. Similarly application of 50\% fertilizer along with FYM and microbial consortia recorded output energy of 39,525 MJ/ha. The lowest output energy 26,475 MJ/ha was attained under sowing across the slope was mainly due to lower grain and stover yield obtained in both the years. Among different moisture conservation treatments paired row planting and opening of furrows in wide rows at 35 DAS gave highest energy use efficiency of 8.90 and energy productivity of 225.78 g/MJ. Among different nutrient management practices 50\% RDF microbial consortia recorded highest energy use efficiency of 15.12 and energy productivity of $370.3 \mathrm{~g} / \mathrm{MJ}$ followed by $50 \%$ RDF + FYM 2.5 t/ha + application of FYM in the above 
Table 4. Mean input and output energy use efficiency and energy productivity of operations under different moisture conservation treatments of rabi sorghum (Pooled).

\begin{tabular}{|c|c|c|c|c|c|}
\hline Treatment & $\begin{array}{l}\text { Application of treatment } \\
\text { and sowing }(\mathrm{MJ} / \mathrm{ha})\end{array}$ & $\begin{array}{c}\text { Total input } \\
\text { energy }(\mathrm{MJ} / \mathrm{ha})\end{array}$ & $\begin{array}{c}\text { Total output } \\
\text { energy (MJ/ha) }\end{array}$ & $\begin{array}{l}\text { Energy use } \\
\text { efficiency }\end{array}$ & $\begin{array}{l}\text { Energy productivity } \\
\text { (g/MJ) }\end{array}$ \\
\hline Sowing across the slope & 161.6 & 4792 & 26475 & 5.52 & 135.6 \\
\hline $\begin{array}{l}\text { Ridges and furrows with tied } \\
\text { ridging }\end{array}$ & 289.44 & 4919 & 33474 & 6.81 & 166.7 \\
\hline $\begin{array}{c}\text { Paired row planting and opening } \\
\text { of furrows in wide rows at } 35 \\
\text { DAS }\end{array}$ & 242.4 & 4872 & 43350 & 8.90 & 225.78 \\
\hline $100 \%$ RDF + FYM 2.5 t/ha & 4057 & 4792 & 37332 & 7.8 & 200.33 \\
\hline $50 \%$ RDF + FYM 2.5 t/ha & 2403.5 & 3138 & 30612 & 9.76 & 242.19 \\
\hline $50 \%$ RDF + Microbial consortia & 2422.18 & 1971 & 29811 & 15.12 & 370.3 \\
\hline $\begin{array}{l}50 \% \text { RDF +FYM } 2.5 \text { t/ha } \\
\text { + Microbial consortia. }\end{array}$ & 2797.18 & 3141 & 39525 & 12.58 & 302.45 \\
\hline
\end{tabular}

RDF: Recommended Dose of Fertilizer; FYM: Farm Yard Manure; DAS: Days After Sowing.

treatment. Among moisture conservation practices paired row planting and opening of furrows in wide rows at 35 DAS recorded higher rain water use efficiency of 5.15 $\mathrm{Kg} / \mathrm{ha} / \mathrm{mm}$ and among nutrient management practices application of 50\% RDF + FYM 2.5 t/ha + microbial consortia recorded higher rain water use efficiency of $4.48 \mathrm{Kg} / \mathrm{ha} / \mathrm{mm}$.

\section{CONCLUSION}

Field experiment was conducted to assess the effect of three moisture conservation and four nutrient management practices on the performance of rabi sorghum at the central dry zone of Karnataka, India during 2007-2008 and 2008-2009. The detailed analyses of variance were carried out to assess the effect of different treatment on grain yield, stover yield, harvest index, rain water use efficiency. After converting the different inputs and outputs to energy, an assessment was also made on the effects of treatments on input and output energy use efficiency in rabi sorghum. Among different input operations fertilizers and manures contributed $84 \%$ of total input energy. Paired row planting and opening of furrows in wide rows at 35 DAS found to be superior for obtaining maximum grain and stover yield, net returns, B:C ratio. Application of 50\% RDF + FYM 2.5 t/ha + microbial consortia was found to be optimum for getting economic optimum yields and return. Based on the observations of input and output energy, paired row planting and opening of furrows in wide rows at 35 DAS was superior for maximum energy use efficiency and energy productivity, including rainwater use efficiency. Though application of 50\% RDF + microbial consortia recorded highest energy use efficiency and productivity application of $50 \%$ RDF + microbial consortia + FYM 2.5 t/ha found necessary for obtaining higher rainwater use efficiency and getting higher yields on a sustainable basis.

\section{REFERENCES}

[1] Kumar, A. and Rana, K.S. (2007) Performance of pigeon pea + green gram intercropping system as influenced by moisture conservation practices and fertility level under rainfed conditions. Indian Journal of Agronomy, 52, 31-35.

[2] Khanapara, V.D., Solanki, R.M. and Mathukia, R.K. (2009) Resource conservation in arid and semi arid regions of Gujarath. Indian Journal of Agronomy, 54, 159-166.

[3] Mahendra, S., Saxena, K.A., Mittal, J.P. and Singh, H.K. (1985) Energy of cropping system. Indian Journal of Agronomy, 30, 1-59.

[4] Jat, M.L.G.R., Shankar, M., P.K. Mishra., Prathap, S., Balyan, J.K. and Jain, L.K. (2011) Effect of moisture conservation practices on productivity, profitability and energy use of maize in a semi-Arid verisol in western India. Arid Land Research and Management, 19, 1-15.

[5] Nema, A. K., Maruthi, G.R., Sankar, S. and Chauhan, P.S. (2008) Selection of superior tillage and fertilizer practices based on rainfall and soil moisture effects on pearl millet yield under semiarid inceptisols. Journal of Irrigation and Drainage Engineering, 134, 361-371. doi:10.1061/(ASCE)0733-9437(2008)134:3(361)

[6] Patidar, M. and Singh, A.K. (2000) Effect of tillage practices on yield, energy use pattern in cluster bean (Cymopsis tetragonoloba L. Taub)—Pearl millet (Pennisetum glaucum L. R. Br.) rotation in arid zone. Journal of Agricultural Engineering, 37, 1-6.

[7] Pacharne, D.T., Sanglikar, R.V. and Pharande, A.L. (2006) Determination of conservation practice factor (p) of the USLE for different conservation practices in Dryland region of Maharashtra. Indian Journal of Dryland Agricultural Research and Development, 21, 40-45.

[8] Das, G. and Goutham, R.C. (2003) Yield and water use efficiency of pearl millet as influenced by moisture con- 
servation methods under rainfed conditions. Annals of Agricultural Research, 24, 78-81.

[9] Patil, E.N., P.M. Choudhari, Pawar, P.P. and Patil, H.E. (2000) Integrated moisture conservation techniques and nutrient management system for pearl millet in semi arid conditions. Indian Journal of Dry land Agriculture and
Development, 21, 85-87.

[10] Rathore, V.S., Singh P. and Gautam, R.C. (2006) Productivity and water use efficiency of rainfed pearlmillet as influenced by planting patterns and integrated nutrient management Indian Journal of Agronomy, 51, 46-48. 